\title{
The Influence of Javanese Speaking Civility in Families to Form Child Character in The $21^{\text {st }}$ Century
}

\author{
Rachma Mutiara Dewi, Zahrotun Nafi', Rahmah Karuniawati, Ratna Hidayah \\ Universitas Sebelas Maret \\ rachmadewi795@gmail.com
}

\section{Article History}

accepted 24/09/2019 approved 01/10/2019 published 01/12/2019

\begin{abstract}
Education in the family is the first education experienced by a child after being born in the world. The family is the main environment forming the character of children. In this 21st century, children are required to have good moral character. Parents should be able to transmit good etiquette to their children. The main task of parents is not only transferring knowledge, but also transferring values to children. The process of transferring knowledge carried out by parents will succeed if done with the right and right principles. Parents as good educators are able to accustom children to speak good, polite, and gentle words. One of them by way of habituating Javanese manners. The purpose of this study is to study 1) The custom of Javanese manners; 2) children's character in the 21st century; 3) Family education; 4) the formation of character in the family through the Javanese language of manners. The result of this goal is the habit of using polite language in a family environment which influences the character formation of children in the 21 st century.
\end{abstract}

Keywords: Family education, javanese language, character

\begin{abstract}
Abstrak
Pendidikan di dalam keluarga merupakan pendidikan pertama yang dialami seorang anak.. Di abad 21 ini, anak dituntut untuk memiliki karakter moral yang baik. Orang tua seharusnya mampu untuk menularkan etiket baik kepada anaknya. Tugas utama orang tua tidak hanya memindahkan pengetahuan saja, tetapi juga memindahkan nilai kepada anak. Proses pemindahan pengetahuan yang dilakukan oleh orang tua akan berhasil apabila dilakukan dengan prinsip yang benar dan tepat. Orang tua sebagai pendidik yang baik mampu membiasakan anak untuk bertutur kata yang baik, santun, dan lembut. Salah satunya dengan cara pembiasaan berbahasa jawa krama. Tujuan kajian ini untuk mempelajari 1) Pembiasaan berbahasa jawa krama; 2) karakter anak di abad 21;3) Pendidikan keluarga; 4) pembentukan karakter di keluarga melalui bahasa jawa krama. Hasil dari tujuan ini yaitu pembiasaan berbahasa krama di lingkungan keluarga berpengaruh terhadap pembentukan karakter anak di abad 21.
\end{abstract}

Kata kunci : Pendidikan keluarga, bahasa Jawa, karakter

Social, Humanities, and Education Studies (SHEs): Conference Series https://jurnal.uns.ac.id/shes

p-ISSN 2620-9284

e-ISSN 2620-9292 


\section{PENDAHULUAN}

Pada abad 21 ini, anak dituntut untuk memiliki karakter yang terdiri dari karakter moral dan karakter kinerja. Karakter moral mencangkup nilai-nilai pancasila, keimanan, ketaqwaan, integritas, kejujuran, keadilan, empati, rasa welas asih, dan sopan santun. Sementara itu, karakter kinerja mencangkup kerja keras, ulet, tangguh, rasa ingin tahu, inisiatif, gigih, kemampuan beradaptasi, dan kepemimpinan, seperti yang diungkapkan oleh Kalimayatullah, dkk (2017: 2). Karakter moral anak dapat dipengaruhi oleh berbagai pihak, antara lain sekolah, masyarakat, keluarga, dsb. Lingkungan yang paling utama dalam membentuk karakter anak adalah lingkungan keluarga. Anak tumbuh dan berkembang dalam lingkungan keluarga. Dan segala perilaku perbuatan maupun ucapan lisan yang dilakukan keluarga dapat mempengaruhi karakter anak. Oleh karena itu, orang tua harus mampu memberikan pendidikan karakter yang benar dan baik kepada anak sejak usia dini, agar anak dapat terbentuk menjadi pribadi yang berkarakter luhur.

Untuk membentuk karakter anak dalam keluarga, perlu adanya komunikasi yang efektif dan menekankan pada kesopanan dan kesantunan terhadap orang tua. Kesantunan adalah bentuk kesopanan dan kehalusan dalam menggunakan bahasa pada saat seseorang berkomunikasi, baik lisan maupun tulisan Kalimayatullah,dkk (2017). Dengan pembiasaan berbahasa yang santun di dalam keluarga dapat menumbuhkan sikap santun anak sehingga anak dapat berbahasa santun baik di lingkungan keluarga maupun masyarakat. Karena usia anak-anak mampu merekam apa yang mereka dengar dan mereka lihat. Bahasa yang diajarkan orang tua kepada anak harus mengandung nilai-nilai kebaikan. Baik atau buruknya tingkat pendidikan seseorang dilihat dari cara berbahasanya.Salah satu yang dapat dilakukan keluarga untuk membentuk kesopanan dan kesantunan anak yaitu dengan pembiasaan berbahasa jawa krama di dalam keluarga.

Eksistensi penggunaan bahasa jawa di lingkungan keluarga dirasa semakin memudar. Hal itu dibuktikan dengan berkurangnya minat penggunaan bahasa jawa dalam lingkungan pergaulan sehari-hari. Seperti halnya yang dikemukakan oleh Suharyo, (2018 : 253), dalam penelitiannya diketahui bahwa generasi muda jawa sudah mulai tidak bangga terhadap bahasa jawa. Sikap bahasanya (terhadap bahasa jawa) cenderung negatif, sedangkan terhadap bahasa indonesia, generasi muda jawa menunjukkan terdapat gejala tidak setia kesadaran atas norma bahasa Indonesia lemah. Dari data pula diketahui nasib bahasa jawa (terutama ragam krama) akan segera ditinggalkan oleh penuturnya pada 2 atau 3 generasi mendatang. Banyak pemuda yang sekarang tidak tahu penerapan sopan santun terhadap yang lebih tua. Lunturnya penggunaan bahasa jawa di lingkungan masyarakat jawa membuat kualitas budi pekerti dan tata krama pemuda jawa menurun. Karena kurang terampil menggunakan bahasa jawa (krama alus) mereka lebih memilih menggunakan bahasa indonesia yang relatif mudah. Menurut Purwadi (2011), Bahwa etika jawa pada intinya mengacu kepada kebudayaaan jawa yang mempunyai nilai dan didasarkan pada pantas dan tidak pantas apabila diterapkan di dalam kehidupan sehari-hari. Apabila seseorang berbahasa jawa dengan orang lain dengan tidak tepat tataran yang digunakan, maka pergaulan dengan orang lain menjadi terganggu, menjadi tidak serasi, menjadi tidak harmonis digdaya. Oleh karena itu diperlukannya penerapan penggunaan bahasa jawa sehari-hari di dalam keluarga.

Tujuan dibuatnya artikel ini antara lain untuk menyadarkan pentingnya penerapan berbahasa jawa krama sejak dini dalam keluarga untuk membentukan karakter anak pada masa saat ini. Dengan pembiasaan bahasa jawa krama, selain dapat membentuk karakter anak, dapat juga sebagai upaya untuk menghidupkan bahasa daerah yang mulai luntur dalam generasi saat ini. 


\section{A. Karakter Anak di Abad 21}

HASIL DAN PEMBAHASAN

Karakter menurut Suyanto (Santoso, 2012) adalah cara berpikir dan berperilaku yang menjadi ciri khas tiap individu untuk hidup dan bekerjasama, baik dalam lingkungan keluarga, masyarakat, bangsa, dan negara. Karakter berkaitan dengan moral seseorang yang ada pada diri setiap individu, dan positif atau sesuatu hal baik bukan yang buruk. Dalam membangun karakter generasi muda tidak terlepas dari budaya kita sendiri dan dalam hal ini harus ada integrasi dari tiga lingkungan yakni keluarga, sekolah, dan masyarakat. (Martini, 2018).

Menurut Singla dalam Pala (2011) ciri-ciri karakter harus mencangkup beberapa hal, keberanian, jiwa keadilan yang baik, integritas, kesopanan, kebaikan, ketekunan, tanggung jawab, toleransi, disiplin diri, menghormati warga sekolah, tanggung jawab untuk keselamatan sekolah, dan menjadi warga negara yang baik.

Karakter seperti itulah yang nantinya akan membantu anak untuk menghadapi masa depannya. Ketika anak memiliki karakter positif maka anak akan mampu bersaing dengan yang lainnya pada abad 21 ini. Setelah memiliki karakter positif tersebut, anak mampu untuk menerima tuntutan yang harus dimiliki pada abad 21, yaitu kemampuan berpikir kritis, kemampuan berkomunikasi, kemampuan berkolaborasi, dan kemampuan untuk memiliki ide-ide kreatif.

Seperti yang sudah dipaparkan diatas bahwa pembentukan karakter dipengaruhi oleh tiga hal, yaitu lingkungan keluarga, sekolah, dan masyarakat. Namun yang paling berperan dalam proses pembentukan karater anak adalah keluarga, artinya jika pendidikan keluarga positif maka anak akan cenderung berkarater positif dan begitu pula sebaliknya.

\section{B. Pendidikan Keluarga}

Keluarga adalah lembaga pendidikan pertama bagi setiap manusia. Keluarga merupakan pihak terpenting atau pihak yang paling berpengaruh terhadap tumbuh kembang setiap individu. Seperti yang diungkapkan Jailani (2014), bahwa keluarga diharapkan mampu menghasilkan anak-anak yang dapat tumbuh menjadi pribadi, serta mampu hidup di tengah-tengah masyarakat. Sekaligus dapat menerima dan mewarisi nilai-nilai kehidupan dan kebudayaan..

Untuk mewujudkan tugas utama orang tua tersebut, maka perlu adanya pendidikan di dalam keluarga atau dapat disebut pendidikan keluarga. Pendidikan keluarga dapat berjalan dengan baik, dengan adanya dukungan dari masing-masing anggota keluarga. Diharapkan semua anggota keluarga berperan dalam mewujudkan pendidikan keluarga yang optimal. Pendidikan keluarga yang dilakukan, sangat penting bagi kehidupan seseorang. Karena dengan pendidikan keluarga, dapat membentuk pribadi yang sesuai. Orang tua adalah teladan bagi anak-anaknya. Setiap perilaku atau perkataan orang tua, akan ditiru oleh anaknya. Maka dari itu, ketika kita menginginkan anak berperilaku dan bertutur kata yang baik, orang tua harus mampu menjadi contoh atau teladan yang baik pula.

\section{Pembentukan Karakter Melalui Bahasa Jawa di Keluarga}

Karakter dapat dibentuk dari banyak lingkungan. Interaksi anak terhadap lingkungan sekitar, berdampak besar terhadap perkembangan karakternya. Karakter yang diharapkan adalah anak memiliki sikap dan perilaku sopan dan santun kepada orang tua. Lingkungan yang paling berpengaruh terhadap perkembangan anak yaitu lingkungan keluarga..

Sesuai dalam buku Soeseno Bachtiar dalam buku yang berjudul Buku Pintar Memahami Psikologi Anak Didik, menjelakan bahwa anak yang dibiasakan bersikap sopan santun akan lebih mudah bersosialisasi dan mau mematuhi aturan umum di masyarakat. Di dalam buku tersebut juga dijelaskan hal-hal penting yang harus diperhatikan orang tua untuk mendidik anak agar cerdas bertatakrama, yaitu: 
1. Orang tua dan guru sebagai model

Anak pasti akan meniru dan mencontoh perilaku orang-orang yang ada di sekitarnya, terutama orang tua dan guru. Oleh karena itu, orang tua dan guru haruslah memberi contoh yang baik, agar terbentuk karakteristik anak yang baik pula.

2. Mulai dari hal kecil

Hal-hal yang dilakukan anak, baik hal kecil atau besar, apabila tidak termonitor oleh orang tua, akan menjadi kebiasaan. Kebiasaan-kebiasaan anak yang baik dapat dipertahankan. Namun, apabila kebiasaan anak bersifat negatif, orang tua perlu memberikan teguran atau perbaikan, agar sikap anak menjadi seperti yang diinginkan. Contoh kebiasaan-kebiasaan yang harus tetap diterapkan yaitu: mengucapkan terima kasih ketika dibantu orang lain, mengucapkan maaf apabila bertindak salah, mengucapkan tolong apabila meminta tolong kepada orang lain, dsb.

3. Jelaskan tujuannya

Selain memberi contoh yang baik, tentunya orang tua harus memberitahu kepada anak, manfaat atau tujuannya berperilaku baik.

4. Harus sejak dini

Orang tua harusnya mengajarkan kepada anak sejak dini, mulai dari hal-hal kecil atau hal-hal mendasar.

Dalam pembentukan karakter sopan santun kepada anak dapat melalui pembiasaan menggunakan bahasa jawa krama di lingkungan keluarga. Kebudayaan jawa khususnya bahasa jawa krama sendiri mengandung nilai-nilai penting dan baik untuk dilakukan pembiasaan seperti norma, andhap asor, sikap hormat dsb.

Menurut Saputro (2017) menyatakan bahwa kata-kata atau bahasa yang ditunjukkan pada orang lain itu yang disebut unggah-ungguhing basa yang terbagi menjadi tiga, yaitu bahasa ngoko, bahasa madya dan bahasa krama. Masing-masing mempunyai makna dan tata krama yang mendalam. Unggah-ungguh adalah tata cara berbahasa sesuai dengan tata krama, yaitu cara berbicara terhadap orang lain dan tingkah laku secara tepat.

Dalam interaksi sosial diharapkan anak akan menggunakan bahasa jawa krama kepada orang tua akan jauh lebih sopan daripada menggunakan bahasa jawa ngoko walaupun masih sama cangkupanya bahasa jawa atau menggunakan bahasa Indonesia. Menggunakan bahasa daerah sendiri dapat menunjukkkan identitas sosial dan ciri suatu daerah pada diri seseorang.

Dalam membentuk karakter anak orang tua menjadi guru dalam mengajarkan kepatuhan dan kesopanan. Proses mengajarkan kesopanan dimulai sejak balita. Saat makan anak dibiasakan untuk memegang makanan yang akan dimakan dengan menggunakan tangan kanan. Memberikan sesuatu kepada orang lain menggunakan tangan kanan. Jika tidak memungkinkan dapat menggunakan tangan kiri dengan mengucapkan "nyuwun sewu". Hal ini akan menumbuhkan karakter kepada anak. Dalam bertutur kata orang tua mencontohkan anak untuk bertutur kata yang baik. dalam berkomunikasi dengan orang lain maupun berkomunikasi dengan anak, orang tua menggunakan bahasa jawa krama, sehingga anak akan mencontoh menggunakan bahasa jawa krama dalam kehidupan sehari-hari.

\section{SIMPULAN}

Pada abad 21 ini, anak dituntut untuk mempunyai karakter moral dan karakter kinerja. Karakter anak yang baik akan menunjukkan kualitas dirinya di dalam masyarakat. Karakter anak dapat dibentuk oleh banyak lingkungan, terutama lingkungan keluarga. Lingkungan keluarga sangat mempengaruhi karakter anak. Yang sangat diperlukan yaitu dalam pembentukan karakter sopan dan santun. Karakter tersebut dapat diajarkan dalam bentuk berbahasa yang baik. Karena berhasil atau 
tidaknya pendidikan orang tua adalah cara berbahasa anak baik atau buruk. Salah satu cara yang dapat dilakukan keluarga untuk membentuk karakter anak yaitu dengan pembiasaan berbahasa jawa krama. Karena bahasa jawa terutama bahasa krama cocok mengandung sarat tentang kebaikan kesopana dan karakter. Dengan begitu, karakter santun anak akan terbentuk dengan mudah, apabila anak sudah dibiasakan dari kecil untuk berbahasa jawa krama.

\section{DAFTAR PUSTAKA}

Bachtiar, S. (2012). Buku Pintar Memahami Psikologi Anak Didik. Yogyakarta: Pinang Merah Publisher

Jailani, M.S. (2014). Teori Pendidikan Keluarga dan Tanggung Jawab Orang Tua dalam Pendidikan Anak Usia Dini. Jurnal Pendidikan Islam, 8 (2), 258.

Kalimayatullah, R, dkk. (2017). Pendidikan Kesantunan di Lingkungan Keluarga. 8 (2): 2. Universitas Pendidikan Indonesia

Martini, E. (2018). Membangun Karakter Generasi Muda Melalui Model Pembelajaran Berbasis Kecakapan Abad 21. Jurnal Pancasila Dan Kewarganegaraan, 3 (2), 26.

Pala, Aynur . (2011). The Need For Character Education. Internasional Jurnal of Social and Humanity Studies, 3 (2).

Purwadi. (2011). Etika Komunikas Dalam Budaya Jawa. Jurnal IImu Komunikasi, 9 (3).

Santoso, I. (2012). Pendidikan Karakter dan Pembelajaran Bahasa Asing Berwawasan Intelektual. Jurnal Pendidikan Karakter, Tahun II. Universitas Negeri Yogyakarta. Yogyakarta.

Suharyo (2018). Nasib Bahasa Jawab dan Bahasa Indonesia dalam Pandangan dan Sikap Bahasa Generasi Muda Jawa. NUSA, 13 (2). Universitas Diponogoro

Saputro, H.G. (2017). Pelaksanaan Pelajaran Bahasa Jawa Materi Krama Inggil di Siswa MI dan SD Muhammadiyah Kecamatan Cilongok. Purwokerto: Universitas Muhammadiyah Purwokerto. 